\title{
FINANCIAL REPORT PREPARATION TRAINING FOR RT (NEIGBOHOOD UNIT) DEVICES IN RW (HAMLET UNIT) ENVIRONMENT 16 BAROS CITY CIMAHI VILLAGE
}

\author{
Khairaningrum Mulyanti ${ }^{1}$, Riani Tanjung ${ }^{2}$, Y. Casmadi $^{3}$ \\ 1 Prodi D4 Akuntansi Keuangan Politeknik Pos Indonesia email; khairingrum@poltekpos.ac.id \\ 2 Prodi D3 Akuntansi Politeknik Pos Indonesia email; rianitanjung@ poltekpos.ac.id \\ 3Prodi D3 Akuntansi Politeknik Pos Indonesia email; casmadi@ poltekpos.ac.id
}

\begin{abstract}
A good governance system is not only a responsibility that must be carried out by the central government, Neighborhood association as the smallest social institution even responsible for implementing the good governance. One form of implementation can be implemented in the form of financial statements in the area. The implementation of good governance has not been fully realized in all RT neighborhoods in Cimahi City, one of them in RW 16, Baros Village. The Community Service activities are expected to increase the awareness of the neighborhood administrators to prepare financial reports in accordance with the rules of simple government accounting standards. The methods used in this activity include lectures, tutorials, and discussions. This PKM activity went well and got good enthusiasm from the RT administrators, and it was hoped that this activity would be the beginning of the implementation of a good governance system.
\end{abstract}

Keywords: Preparation of Financial Statements at the level of Neighborhood Unit, Government Accounting System.

\section{Abstrak}

Sistem pemerintahan yang baik bukan hanya tanggung jawab yang harus diemban oleh pemerintah pusat, Rukun tetangga sebagai Lembaga kemasyarakatan terkecil sekalipun bertanggung jawab dalam pelaksanaan good governance tersebut. Salah satu bentuk dari pelaksanaannya dapat diimplementasikan dalam bentuk pelaporan keuangan yang ada di area-nya. Pelaksanaan good governance belum sepenuhnya terwujud di seluruh lingkungan RT di Kota Cimahi, salah satunya di RW 16 Kelurahan Baros. Kegiatan Pengabdian Kepada Masyarakat ini diharapkan dapat meningkatkan kesadaran para pengurus RT untuk menyusun laporan keuangan sesuai dengan kaidah standar akuntansi pemerintahan yang sederhana. Metode yang digunakan dalam kegiatan ini meliputi ceramah, tutorial, dan diskusi. Kegiatan PKM ini berjalan lancar dan mendapatkan antusias yang baik dari para pengurus RT, dan diharapkan kegiatan ini menjadi awal dari terlaksananya sistem pemerintahan yang baik.

Kata Kunci: Penyusunan Laporan Keuangan tingkat RT, Sistem Akuntansi Pemerintahan 


\section{Pendahuluan}

Walaupun sebagai lembaga kemasyarakatan yang memiliki lingkup wilayah terkecil, Rukun tetangga merupakan tingkat pemerintahan yang paling rendah yang harus dikelola dengan baik sesuai dengan sistem pemerintahan yang baik (good governance). Pengelolaan yang baik ini tidak hanya berlaku bagi pelayanan yang diberikan oleh para pengurusnya, tetapi juga menjangkau mengenai pengelolaan sumber dana yang diterima melalui iuran swadaya masyarakatnya. Mengacu pada prinsip good govarnance, pengelolaan dana RT maupun RW harus dilakukan secara akuntabel dan transparan. Salah satu upayanya adalah penyampaian laporan pertanggungjawaban keuangan yang tepat waktu dan sesuai dengan standar akuntansi pemerintahan. Hal tersebut sudah tertuang dalam Peraturan Pemerintahan RI Nomor 24 Tahun 2005 tentang Standar Akuntansi Pemerintahan (SAP). Pernyataan dalam standar tersebut adalah prinsip-prinsip akuntansi yang diterapkan dalam menyusun dan menyajikan laporan keuangan pemerintah di Indonesia. Pemerintahan yang dimaksud dalam peraturan tersebut adalah pemerintahpusat dan/atau pemerintah daerah. Daerah yang dimaksud, juga untuk daerah tingkat I (Provinsi) dan tingkat II (Kotamadya/Kabupaten) serta satuan organisasi di lingkungan pemerintah pusat/daerah atau organisasi lainnya.

Dari pernyataan di atas, tentu saja RT maupun RW merupakan satuan organisasi yang berada dalam pemerintah daerah yang merupakan organisasi sektor publik yang dalam pengelolaan dananya harus mengacu pada Standar Akuntansi Pemerintahan. Termasuk di lingkungan RW 16 Kelurahan Baros Kota Cimahi ini. Sebagai salah satu bagian dari organisasi sektor publik, RT-RT yang berada dalam lingkup RW 16 Kelurahan Baros Kota Cimahi sudah seharusnya menyusun laporan keuangan yang merupakan pertanggungjawaban keuangan dari perolehan sejumlah dana yang bersumber dari swadaya masyarakat. Tetapi dalam praktiknya, RT-RT yang berada dalam wilayah RW 16 Kelurahan Baros kota Cimahi ini belum menyusun laporan keuangannya dengan baik. Bahkan ada beberapa RT yang belum menyusun Laporan Keuangan sebagai bentuk pertanggungjawaban tersebut. Oleh sebab itu, kegiatan Pengabdian Kepada Masyarakat ini bertujuan untuk memberikan pelatihan kepada para pengurus RT di lingkungan RW 16 Kelurahan Baros Kota Cimahi sesuai dengan Standar Akuntansi Pemerintahan yang sederhana namun berdasarkan prinsip akuntabel dan transaparan.

\section{Metode Pelaksanaan}

Pelaksanaan kegiatan Pengabdian Kepada Masyarakat ini dilakukan dengan menggunakan metode ceramah, tutorial, dan diskusi. Metode pelaksanaan tersebut dapat dijelaskan dalam langkah-langkah sebagai berikut:

1. Metode Ceramah

Peserta pelatihan diberikan motivasi yang dapat membangun kesadaran mengenai pentingnya penyusunan laporan keuangan RT sesuai dengan Standar Akuntansi Pemerintahan yang sederhana dan akuntabel. Dalam pelaksanaannya metode ini dilaksanakan selama 1 jam

2. Metode Tutorial

Peserta pelatihan diberikan materi bagaimana menyusun laporan keuangan RT yang sederhana, memadai dan sesuai dengan Standar Akuntansi Pemerintahan sebagai bentuk pertanggungjawaban kepada masyarakat atas pendanaan yang bersumber dari 
swadaya masyarakat. Metode ini diselenggarakan selama 3 jam.

\section{Metode Diskusi}

Peserta pelatihan diberikan kesempatan untuk mendiskusikan permasalahan yang berkaitan dengan penyusunan laporan keuangan yang selama ini dihadapi.metode ini dilaksanakan selama 1 jam.

\section{Hasil dan Pembahasan}

Kegiatan Pelatihan Penyusunan Laporan Keuangan Bagi Perangkat RT (Rukun Tetangga) di Lingkungan RW (Rukun Warga) 16 Kelurahan Baros Kota Cimahi yang diadakan pada hari Rabu tanggal 18 Juli 2018 berjalan dengan lancar. Pelatihan diawali dengan pengantar dari ketua RW 16 Baros. Selanjut yaitu sesi pertama dibuka dengan metode ceramah mengenai materi dasar aturan dan bentuk dari penyusunan laporan keuangan sesuai dengn kaidah-kaidah akuntansi yang berlaku. Selain itu pemateri juga memberikan ilustrasi penyusunan laporan keuangan di lingkungan masyarakat dalam pengelolaan dana swadaya masyarakat.

Pada sesi kedua diisi dengan ilustrasi penyusunan laporan keuangan salah satu RT yang ada di lingkungan RW 16 Kelurahan Baros. Dari hasil wawancara yang dilakukan tim peneliti pada saat analisis situasi adalah setiap RT dilingkungan RW 16 ini tidak pernah menyampaiakan laporan secara rinci mengenai pemasukan dan pengeluaran yang dilakukan. Hal tersebut juga pada akhirnya mempengaruhi catatan keuangan yang ada dilingkung RW. Para pengurus RW tidak menyusun laporan keuangan dengan baik karena merasa tidak ada data yang cukup dari para pengurus RT karena di lingkungan tersebut satu-satunya dana hanya didapatkan dari swadaya masyarakat.

Sesi ketiga diisi dengan tanya jawab. Pada sesi ini peserta menunjukan antusias bertanya kepada tim peneliti. Beberapa pertanyaan yang diajukan oleh peserta pelatihan adalah mengenai teknis penyusunan laporan keuangan apakah harus dilaporkan setiap bulan, karena ada beberapa anggota masyarakat di lingkungan RTnya yang tidak menyetorkan uang iuran tiap bulannya dikarenakan keadaan ekonomi.

\section{KESIMPULAN}

Kegiatan Pengabdian Kepada Masyarakat dengan kegiatan Pelatihan Penyusunan Laporan Keuangan Bagi Perangkat RT (Rukun Tetangga) di Lingkungan RW (Rukun Warga) 16 Kelurahan Baros Kota Cimahi telah berjalan dengan lancar. Semua peserta cukup antusias mengikuti acara hingga selesai dan merasakan manfaatnya bagi pelaporan keuangan dari hasil swadaya masayarakat di lingkungannya. Walaupun ada beberapa hambatan yang ditemui oleh tim peneliti dalam pelaksanaan kegiatan pengabdian ini, diantaranya latar belakang para pengurus RT dan RW di lingkungan ini cukup bervariasi sehingga daya tangkap para peserta terhadap materi yang disampaikan oleh tim peneliti juga bervariasi. Beberapa peserta yang sudah cukup sepuh terlihat kesulitan memahami mengenai penyusunan laporan keuangan. Selain itu para peserta juga belum memiliki pengetahuan mengenai laporan keuangan sesuai dengan kaidah-kaidah akuntansi, sehingga beberapa peserta mengalami kesulitan dalam praktiknya. 


\section{REFERENSI}

Undang-Undang Republik Indonesia NO 9 Tahun 2001 tentang Pembentukan Kota Cimahi Peraturan Kota Bandung Nomor 04 Tahun 2010 Tentang Rukun Tetangga dan Rukun Warga Peraturan Pemerintah Nomor 24 Tahun 2005 Tentang Standar Akuntansi Pemerintahan http://jabar.tribunnews.com/2018/03/19/janji- wali-kota-cimahi-mau-ngasih-duit-rp-100juta- per-rw-belum-terbukti (16 April 2018). 